\title{
A reciprocal autosomal translocation which causes male sterility in the mouse also impairs oogenesis
}

\author{
P. S. Burgoyne, S. Mahadevaiah* and U. Mittwoch* \\ MRC Mammalian Development Unit, Wolfson House, 4 Stephenson Way, London NWI 2HE, and \\ *Department of Genetics and Biometry, University College London, Wolfson House, 4 Stephenson Way, \\ London NWI 2HE, U.K.
}

\begin{abstract}
Summary. A quantitative histological analysis of ovaries from 3- and 5-day-old female mice heterozygous for the male-sterile reciprocal autosomal translocation, $\mathrm{T}(11 ; 19) 42 \mathrm{H}$, revealed a marked reduction (by $65 \%$ ) in the number of oocytes as compared to controls. These findings call into question the widely held view that chromosomal anomalies causing spermatogenic failure have no effect on oogenesis. It is suggested that during meiosis in males and females there is a mechanism operating which tends to eliminate cells which had incomplete chromosome pairing at the pachytene stage.
\end{abstract}

\section{Introduction}

Heterozygosity for certain reciprocal autosomal translocations is one of a number of chromosomal causes of male sterility in mice (Lyon \& Meredith, 1966; Searle, 1982). Females carrying these male-sterile translocations typically have reduced fertility due to death in utero of chromosomally unbalanced embryos (de Boer \& de Maar, 1976; Beechey, Kirk \& Searle, 1980). Although Beechey, de Boer \& van der Hoeven (1976) found evidence of premature ovarian failure in a tertiary trisomic, it has generally been assumed that oogenesis is unaffected.

Thus, Forejt (1982) asks "Why is only male fertility affected, while oogenesis is not impaired in the presence of chromosome rearrangement?" However, Mittwoch, Mahadevaiah \& Olive (1981) reported that at 3 and 5 days after birth the ovaries of female mice heterozygous for the male-sterile reciprocal autosomal translocation, $\mathrm{T}(11 ; 19) 42 \mathrm{H}$ (hereafter abbreviated $\mathrm{T} 42 \mathrm{H}$ ), were $30 \%$ smaller than those of their chromosomally normal sisters. Subsequently, Mittwoch, Mahadevaiah \& Setterfield (1984) have shown that ovarian size is also reduced in 3-7-day-old females carrying two other male-sterile chromosomal anomalies (an insertion and a tertiary trisomy). This has led these authors to question whether oogenesis is unaffected by chromosomal anomalies which cause male sterility. Burgoyne \& Baker (1984) also concluded that chromosomal anomalies causing male sterility affect oogenesis, after realizing the parallels between the spermatogenic impairment in sterile XO Sxr male mice (Cattanach, Pollard \& Hawkes, 1971) and the oogenic impairment in XO female mice (Burgoyne \& Baker, 1985).

In the present paper we show that the reduced ovarian size in $\mathrm{T} 42 \mathrm{H} /+$ female mice is associated with a marked reduction in the number of oocytes.

\section{Materials and Methods}

The ovaries analysed in this study were $\mathrm{T} 42 \mathrm{H} /+$ and $+/+$ ovaries for which ovarian volume data had been collected by Mittwoch et al. (1981) together with ovaries from an additional 3-day-old $\mathrm{T} 42 \mathrm{H} /+$ with a $+/+$ sib pair. All ovaries had been fixed in Bouin's fixative, embedded in paraffin 
Table 1. Ovarian volumes, tissue volumes and numbers of oocytes for $+/+$ and $T 42 \mathrm{H} /+$ ovaries of mice at 3 and 5 days post partum

\begin{tabular}{|c|c|c|c|c|c|c|c|c|}
\hline \multirow[b]{2}{*}{$\begin{array}{l}\text { Litter } \\
\text { no. }\end{array}$} & \multirow[b]{2}{*}{$\begin{array}{c}\text { Age } \\
\text { (days) }\end{array}$} & \multirow[b]{2}{*}{$\begin{array}{c}\text { Mouse } \\
\text { no. }\end{array}$} & \multirow[b]{2}{*}{ Genotype } & \multirow{2}{*}{$\begin{array}{c}\begin{array}{c}\text { Independent* } \\
\text { estimates }\end{array} \\
\begin{array}{c}\text { Ovarian vol. } \\
\left(\mathrm{mm}^{3} \times 10^{-5}\right)\end{array}\end{array}$} & \multicolumn{4}{|c|}{ Distributed point count estimates } \\
\hline & & & & & $\begin{array}{l}\text { Ovarian vol. } \\
\left(\mathrm{mm}^{3} \times 10^{-5}\right)\end{array}$ & $\begin{array}{c}\text { Somatic } \\
\text { tissue vol. } \\
\left(\mathrm{mm}^{3} \times 10^{-5}\right)\end{array}$ & $\begin{array}{c}\text { Germinal } \\
\text { tissue vol. } \\
\left(\mathrm{mm}^{3} \times 10^{-5}\right)\end{array}$ & $\begin{array}{l}\text { No. of } \\
\text { oocytes }\end{array}$ \\
\hline 4 & 5 & $\begin{array}{l}16 \\
15\end{array}$ & $\begin{array}{r}+/+ \\
\mathrm{T} 42 \mathrm{H} /+\end{array}$ & $\begin{array}{l}7000 \\
5140\end{array}$ & $\begin{array}{l}7044 \\
5046\end{array}$ & $\begin{array}{l}5863 \\
4521\end{array}$ & $\begin{array}{r}1181 \\
525\end{array}$ & $\begin{array}{l}6779 \\
1990\end{array}$ \\
\hline 7 & 5 & $\begin{array}{l}26 \\
25\end{array}$ & $\begin{array}{r}+/+ \\
\mathrm{T} 42 \mathrm{H} /+\end{array}$ & $\begin{array}{l}6530 \\
4720\end{array}$ & $\begin{array}{l}6825 \\
4638\end{array}$ & $\begin{array}{l}5119 \\
3967\end{array}$ & $\begin{array}{r}1706 \\
671\end{array}$ & $\begin{array}{r}10689 \\
3622\end{array}$ \\
\hline 10 & 5 & $\begin{array}{l}33 \\
34 \\
32\end{array}$ & $\begin{array}{r}+1+ \\
+1+ \\
\mathrm{T} 42 \mathrm{H} /+\end{array}$ & $\begin{array}{r}8630 \\
10590 \\
6750\end{array}$ & $\begin{array}{r}8006 \\
10806 \\
7284\end{array}$ & $\begin{array}{l}6912 \\
8837 \\
6168\end{array}$ & $\begin{array}{l}1094 \\
1969 \\
1116\end{array}$ & $\begin{array}{r}7732 \\
10428 \\
1728\end{array}$ \\
\hline 12 & 5 & $\begin{array}{l}38 \\
39\end{array}$ & $\begin{array}{r}+/+ \\
\mathrm{T} 42 \mathrm{H} /+\end{array}$ & $\begin{array}{r}15280 \\
7810\end{array}$ & $\begin{array}{r}15444 \\
7350\end{array}$ & $\begin{array}{r}12644 \\
6606\end{array}$ & $\begin{array}{r}2800 \\
744\end{array}$ & $\begin{array}{r}11310 \\
2426\end{array}$ \\
\hline 13 & 3 & $\begin{array}{l}41 \\
40 \\
43\end{array}$ & $\begin{array}{r}+/+ \\
\mathrm{T} 42 \mathrm{H} /+ \\
\mathrm{T} 42 \mathrm{H} /+\end{array}$ & $\begin{array}{l}4980 \\
3950 \\
4890\end{array}$ & $\begin{array}{l}5469 \\
4091 \\
5228\end{array}$ & $\begin{array}{l}3544 \\
3282 \\
4287\end{array}$ & $\begin{array}{r}1925 \\
809 \\
941\end{array}$ & $\begin{array}{r}10623 \\
3261 \\
4404\end{array}$ \\
\hline 24 & 3 & 72 & $+1+$ & 5440 & 5753 & 4769 & 984 & $\begin{array}{c}4768 \\
(5476) \dagger\end{array}$ \\
\hline & & 73 & $\mathrm{~T} 42 \mathrm{H} /+$ & 5030 & 5403 & 4353 & 1050 & $\begin{array}{c}4966 \\
(5460) \dagger\end{array}$ \\
\hline 112 & 3 & $\begin{array}{l}277 \\
278\end{array}$ & $\begin{array}{r}+/+ \\
\mathrm{T} 42 \mathrm{H} /+\end{array}$ & $\begin{array}{l}5340 \\
3270\end{array}$ & $\begin{array}{l}5228 \\
3675\end{array}$ & $\begin{array}{l}4178 \\
3252\end{array}$ & $\begin{array}{r}1050 \\
423\end{array}$ & $\begin{array}{l}5657 \\
2219\end{array}$ \\
\hline & Mean & $\begin{array}{r}\text { M } \\
\text { weighted }\end{array}$ & $\begin{array}{r}\text { Mean }+1+\ddagger \\
\text { ean T42H } /+\bar{t} \\
\text { d difference }(\bar{d}) \\
\text { s.e. } \bar{d} \\
\bar{d} / \text { s.e. } \bar{d}=\mathrm{t}_{6} \\
P \text { (two-tailed) }\end{array}$ & $\begin{array}{c}7740 \\
5306 \\
2370 \\
874 \\
2 \cdot 71 \\
0 \cdot 05-0 \cdot 01\end{array}$ & $\begin{array}{c}7881 \\
5437 \\
2358 \\
944 \\
2 \cdot 50 \\
0 \cdot 05-0 \cdot 01\end{array}$ & $\begin{array}{c}6284 \\
4664 \\
1541 \\
756 \\
2 \cdot 04 \\
0 \cdot 1-0 \cdot 05\end{array}$ & $\begin{array}{c}1597 \\
772 \\
817 \\
243 \\
3.36 \\
0.05-0.01\end{array}$ & $\begin{array}{c}8415 \\
2977 \\
5581 \\
1118 \\
4.99 \\
0.005-0.001\end{array}$ \\
\hline
\end{tabular}

* Independent estimates of ovarian volume derived from section area measurements made using a modified Whipple eyepiece (Mittwoch et al., 1981) or a digitiser table (Mice 277 and 278).

$\dagger$ Oocyte numbers estimated by reconstruction.

$\ddagger$ Means of litter means.

wax, serially sectioned at $7 \mu \mathrm{m}$ and stained with haematoxylin and eosin. Since differences in ovarian volume between mice and between genotypes greatiy exceed differences within mice (left ovary versus right ovary) it was decided to analyse only one ovary from each mouse.

The methods used for the estimation of tissue volumes and numbers of oocytes for each ovary were those described by Burgoyne \& Baker (1985). Briefly, the volume of somatic and of germinal tissue was estimated using an evenly distributed point count. During this sampling procedure an estimate of the oocyte size distribution was obtained, enabling a mean oocyte volume to be calculated. Dividing the germinal volume by the mean oocyte volume estimates the number of oocytes in that ovary.

In addition, the oocyte numbers for two ovaries (from Mice 72 and 73) were estimated by reconstruction. All sections were photographed and oocyte outlines traced from the prints on acetate sheets. By superimposing acetate sheets, oocytes appearing in more than one section could be identified.

Because there is considerable variation between litters, comparisons were made between genotypes within litters. For each litter the difference $(d)$ between the $+/+$ and $\mathrm{T} 42 \mathrm{H} /+$ means 


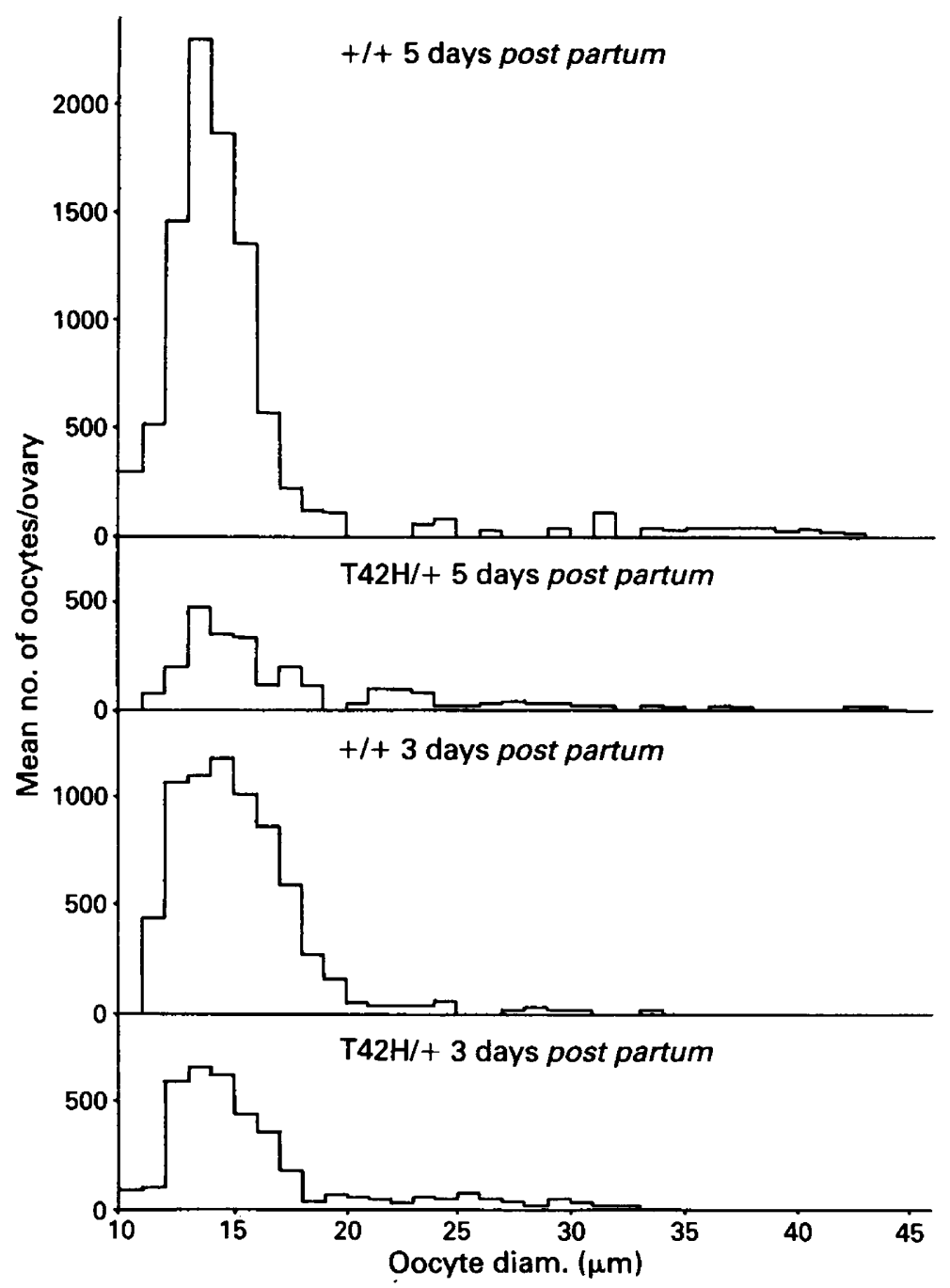

Text-fig. 1. Oocyte size distributions for $+/+$ and $\mathrm{T} 42 \mathrm{H} /+$ ovaries at 5 and 3 days post partum as estimated by the distributed point count method of Burgoyne \& Baker (1985).

was calculated, and then assigned a weight according to the formula $w=n_{1} n_{2} /\left(n_{1}+n_{2}\right)$ where $n_{1}$ and $n_{2}$ are the numbers of $+1+$ and $\mathrm{T} 42 \mathrm{H} /+$ mice in the litter. The mean weighted difference, $\bar{d}=\Sigma w d / \Sigma w$, and its standard error, s.e. $\bar{d}=\sqrt{[}\left[\frac{1}{(N-1) \Sigma w}\left(\Sigma w d^{2}-\frac{(\Sigma w d)^{2}}{\Sigma w}\right)\right]$, where $N$ is the number of litters.

\section{Results}

Table 1 summarizes the results from the quantitative histological analysis of $\mathrm{T} 42 \mathrm{H} /+$ and $+/+$ ovaries. Also included in the table are the oocyte counts obtained by reconstruction for Mice 72 and 73, and independent estimates of ovarian volume obtained (except for those for litter 112) in the course of the study by Mittwoch et al. (1981). The ovarian volume estimates obtained by the 
'distributed point-count method' described by Burgoyne \& Baker (1985) are in good agreement with the independent estimates. The $\mathrm{T} 42 \mathrm{H} /+$ ovaries are estimated to be $31 \%$ smaller than $+/+$ ovaries by both methods.

The histological analysis reveals that the smaller size of $\mathrm{T} 42 \mathrm{H} /+$ ovaries is due to a reduction in both somatic tissue volume (by $26 \%$ ) and germinal tissue volume (by $52 \%$ ) although the reduction in somatic tissue is not quite significant. When the amount of germinal tissue is expressed as the number of oocytes, the reduction is even greater $(65 \%)$ because the mean oocyte size is greater in $\mathrm{T} 42 \mathrm{H} /+$ than in $+/+$ ovaries. The reason for this increased mean oocyte size is apparent in Text-fig. 1, which gives the estimated distribution of oocyte size in $\mathrm{T} 42 \mathrm{H} /+$ and $+/+$ ovaries at 3 and 5 days. Although the pool of small oocytes is severely reduced in $\mathrm{T} 42 \mathrm{H} /+$ ovaries, the population of growing oocytes is normal with respect to both the size distribution and number of oocytes. At 5 days after birth, when the growing oocytes are clearly demarcated (diameter $>20 \mu \mathrm{m}$ ), there is an average of 587 growing oocytes in $\mathrm{T} 42 \mathrm{H} /+$ ovaries and 599 in $+/+$ ovaries.

The oocyte counts obtained by reconstruction for the ovaries from Mice 72 and 73 are higher than the estimates obtained from the histological analysis. It is not clear which figures are closer to the true values, since reconstruction can overestimate oocyte numbers when no allowance is made for section distortion (see Burgoyne \& Baker, 1985). This pair of ovaries is unusual in not showing the otherwise consistently large difference in oocyte numbers between $+/+$ and $\mathrm{T} 42 \mathrm{H} /+$. This is mainly due to a particularly low oocyte count in the control ovary.

\section{Discussion}

The ovaries of mice increase in size rapidly in the days after birth (Burgoyne \& Baker, 1985) due to the growth of a subset of the oocytes and the proliferation of the follicle cells which surround them. This establishes the 'growing population' of oocytes, which is continuously supplemented by growth of oocytes from the 'pool', and is depleted by atresia and eventually by ovulation.

The reduced ovarian volume seen postnatally in XO mice (Burgoyne \& Baker, 1985) is due in part to a delay in the establishment of the 'growing population', which is a reflection of the overall retardation of XO mice, and in part to a deficiency of 'pool' oocytes. The results obtained here show that in $\mathrm{T} 42 \mathrm{H} /+$ mice the establishment of the growing population of oocytes is normal, and that the reduced ovarian volume is due entirely to a marked deficiency of 'pool' oocytes and their enveloping follicle cells. We have therefore established that heterozygosity for $\mathrm{T} 42 \mathrm{H}$, which results in spermatogenic arrest in males, leads to a $65 \%$ reduction in the number of oocytes in females aged 3-5 days. From work in progress it is clear that the reduced volume of $\operatorname{Ts}\left(5^{12}\right) 31 \mathrm{H} /+$ ovaries (Mittwoch et al., 1984) is also associated with oocyte deficiency (L. A. Setterfield \& U. Mittwoch, unpublished), so we are confident that impaired oogenesis will prove to be a feature of female carriers of other male-sterile chromosomal anomalies.

Although females are affected the gametogenic failure is less severe than in males. In considering why this should be we will compare $\mathrm{XO}$ female with $\mathrm{XO} S x r$ male mice, and $\mathrm{T} 42 \mathrm{H} /+$ females with $\mathrm{T} 42 \mathrm{H} /+$ males.

In XO females and XO Sxr males the initial phases of gametogenic impairment are similar in that, despite considerable losses at the pachytene stage, many cells reach diplotene. In XO females, those oocytes that reach the diplotene stage are subsequently depleted at normal rates (Burgoyne $\&$ Baker, 1981), can complete meiosis, and produce normal numbers of eggs per cycle (Morris, 1968), although the shortage of oocytes does result in a shortened reproductive lifespan (Lyon \& Hawker, 1973). However in XO Sxr males the second meiotic division is frequently omitted so that as many as $92 \%$ of spermatids may be diploid (Burgoyne \& Baker, 1984; E. R. Levy \& P. S. Burgoyne, unpublished data). Many of these spermatids degenerate and spermiogenesis generates only a few very abnormal spermatozoa with consequent sterility. As discussed by Burgoyne \& Baker (1984) a mechanism which removes meiotic cells carrying chromosomes that were unpaired or incompletely 
paired during pachytene (Miklos, 1974) may explain the gametogenic impairment in these XO male and female mice with unpaired $\mathrm{X}$ chromosomes. The more complete failure in the male might be due to the complexities of spermiogenesis, or perhaps the meiotic arrest at diplotene during oogenesis allows time for damage to be repaired.

Although studied in less detail, $\mathrm{T} 42 \mathrm{H} /+$ females are essentially similar to XO females in that a proportion (35\% of normal) of oocytes reach diplotene and these diplotene oocytes function normally. However, $\mathrm{T} 42 \mathrm{H} /+$ males, in contrast to XO $S x r$ males, show a very abrupt and complete arrest in mid-pachytene, no diplotene spermatocytes being formed (de Rooij, 1980). This suggests that, in addition to the losses which may be a consequence of the incomplete pairing in the translocation quadrivalent, another factor must be operating which causes further problems at the pachytene stage. Forejt (1982) has been a strong proponent of the idea that inactivation of the X chromosome in early pachytene is a prerequisite for spermatogenesis (Lifschytz \& Lindsley, 1972) and that rearranged autosomes by association with the unpaired part of the $\mathrm{X}$ can interfere with this process. In XO $S x r$ males there is nothing to interfere with the inactivation of the X chromosome, but in $\mathrm{T} 42 \mathrm{H} /+$ males $88 \%$ of pachytene spermatocytes show univalent or multivalent contact with the XY body ('sex vesicle') (de Boer, Searle, van der Hoeven \& Beechey, 1980).

In conclusion, we have shown that oogenesis is affected by chromosomal anomalies which cause male sterility. We suggest that in males and females a mechanism is operating which removes cells carrying chromosomes that were unpaired or incompletely paired at the pachytene stage. In males, chromosomal anomalies may cause additional damage during pachytene by interfering with the normal silencing of the $\mathrm{X}$ chromosome.

We thank Leslie A. Setterfield for expert technical assistance. We also gratefully acknowledge financial support from The Wellcome Trust and from The Royal Society.

\section{References}

Beechey, C.V., de Boer, P. \& van der Hoeven, F.A. (1976) Egg counts in the ovaries of normal and tertiary trisomic $\left(\mathrm{Ts}\left[1^{13}\right] 70 \mathrm{H}\right)$ female mice. Mouse News Letter 54, 53.

Beechey, C.V., Kirk, M. \& Searle, A.G. (1980) A reciprocal translocation induced in an oocyte and affecting fertility in male mice. Cytogenet. Cell Genet. 27, 129-146.

Burgoyne, P.S. \& Baker, T.G. (1981) Oocyte depletion in $\mathrm{XO}$ mice and their XX sibs from 12 to 200 days post partum. J. Reprod. Fert. 61, 207-212.

Burgoyne, P.S. \& Baker, T.G. (1984) Meiotic pairing and gametogenic failure. In Controlling Events in Meiosis, pp. 349-362. Eds C. W. Evans \& H. G. Dickinson. Company of Biologists, Cambridge.

Burgoyne, P.S. \& Baker, T.G. (1985) Perinatal oocyte loss in XO mice and its implications for the aetiology of gonadal dysgenesis in XO women. J. Reprod. Fert. $75,633-645$

Cattanach, B.M., Pollard, C.E. \& Hawkes, S.G. (1971) Sex-reversed mice: $\mathrm{XX}$ and $\mathrm{XO}$ males. Cytogenetics 10, 318-337.

de Boer, P. \& de Maar, P.H.M.D. (1976) A histological study of embryonic death caused by heterozygosity for the $\mathrm{T} 26 \mathrm{H}$ reciprocal mouse translocation. $J$. Embryol. exp. Morph. 35, 595-606.

de Boer, P., Searle, A.G., van der Hoeven, F.A. \& Beechey, C.V. (1980) Spermatocyte meiotic pairing of the $\mathrm{T}(5 ; 12) 31 \mathrm{H}, \mathrm{T}(6 ; 12) 32 \mathrm{H}, \mathrm{T}(11 ; 19) 42 \mathrm{H}$ male sterile and the $T(1 ; 13) 70 \mathrm{H}$ male-fertile reciprocal translocations in the mouse using silver staining of synaptonemal complexes. Cytogenet. Cell Genet. 27, 202, Abstr.

de Rooij, D.G. (1980) Spermatogenesis in mice heterozygous for a male sterile translocation $(\mathrm{T} 31 \mathrm{H}, \mathrm{T} 32 \mathrm{H}$, $\mathrm{T} 40 \mathrm{H}$ or $\mathrm{T} 42 \mathrm{H}$ ). Cytogenet. Cell Genet. 27, 210-211, Abstr.

Forejt, J. (1982) X-Y involvement in male sterility caused by autosome translocations-a hypothesis. In Genetic Control of Gamete Production and Function, pp. 135-151. Eds P. G. Crosignani, B. L. Rubin \& M. Fraccaro. Academic Press, London.

Lifschytz, E. \& Lindsley, D.L. (1972) The role of Xinactivation during spermatogenesis. Proc. natn. Acad. Sci. U.S.A. 69, 182-186.

Lyon, M.F. \& Hawker, S.G. (1973) Reproductive lifespan in irradiated and unirradiated XO mice. Genet. Res. 21, 185-194.

Lyon, M.F. \& Meredith, R. (1966) Autosomal translocation causing male sterility and viable aneuploidy in the mouse. Cytogenetics 5, 335-354.

Miklos, G.L.C. (1974) Sex-chromosome pairing and male sterility. Cytogenet. Cell Genet. 13, 558-577.

Mittwoch, U., Mahadevaiah, S. \& Olive, M.B. (1981) Retardation of ovarian growth in male-sterile mice carrying an autosomal translocation. J. med. Genet. 8, 414-417.

Mittwoch, U., Mahadevaiah, S. \& Setterfield, L.A. (1984) 
Chromosomal anomalies that cause male sterility in the mouse also reduce ovary size. Genet. Res. 44, 219-224.

Morris, T. (1968) The XO and OY chromosome constitutions in the mouse. Genet Res. 12, 125-137.
Searle, A.G. (1982) The genetics of sterility in the mouse. In Genetic Control of Gamete Production and Function, pp. 93-114. Eds P. G. Crosignani, B. L. Rubin \& M. Fraccaro. Academic Press, London.

Received 3 May 1985 